\title{
BYLY RESTITUČNÍ PROCESY V ČR POUZE NÁPRAVOU MAJETKOVÝCH KR̆IVD, ANEBO BYLY ZÁJMOVÝMI SKUPINAMI ZNEUŽITY K DOBÝVÁNÍ RENTY?
}

\section{Tomáš Hřebík*}

\section{Karel Zeman: Analýza restitučních procesů v České republice}

Praha: Nakladatelství Karolinum, 2015. 1. vydání. 188 stran. ISBN: 978-88-024-6295-44.

Byly restituční procesy v ČR pouze nápravou majetkových křivd, anebo byly zájmovými skupinami zneužity k dobývání renty, př́ípadně k založení nových nerovností?

Odpověd' na výše uvedenou hypotézu nalezne jak odborná, tak laická veřejnost v monografii Karla Zemana. Jedná se zcela nepochybně o první odbornou publikaci, která zkoumá problematiku restitučních procesů, likvidace státních podniků, konkurzů státních podniků neboli insolvenčních řízení a transformace státního majetku do vlastnictví obcí. V této souvislosti vystává otázka, proč tyto velmi významné a dlouhodobé ekonomické a národohospodářské procesy zatím nikdo nepodrobil odbornému zkoumání.

Privatizační části tohoto procesu se autor věnuje v samostatné publikaci Analýza privatizačního procesu v České republice, která má s touto knihou společný cíl, tj. seznámit všechny čtenáře, od studentů ekonomie, přes širokou veřejnost až po odborníky $\mathrm{v}$ národohospodářské sféře s průběhem a důsledky restitučních procesů, a to zcela bez zábran. Kde je potřeba, autor nešetří oprávněnou kritikou na nevhodně zvolené postupy, předkládá přesná a objektivní data, vedoucí k pochopení procesů a jejich vyhodnocení.

Na necelých dvou stech stránkách jsou postupně v pěti kapitolách rozebrány nejprve ekonomické teorie vztahující se ke změnám vlastnických práv, dále analýza restitučních procesů z hlediska právního rámce, následně z pohledu institucionálního zajištění, následuje analýza realizace jednotlivých procesů, zakončená závěry analýz jednotlivých procesů. Třetí kapitola se věnuje procesu likvidace státních podniků, opět nejprve skrze právní rámec a institucionální zajištění, následuje analýza samotného procesu a závěry z ní vyplývající. V kapitole čtvrté máme možnost nahlédnout do konkurzních procesů neboli insolvenčních řízení státních podniků, vše je opět řešeno z mnoha úhlů pohledu, jak právních a institucionálních, tak analytických. Poslední kapitola, po níž následuje závěrečné shrnutí, je rozborem procesu transformace státního majetku do vlastnictví obcí. Kapitola je strukturována jako v předchozích případech se stejnými aspekty, které umožňují pohodlnější orientaci v textu a snadné porovnání jednotlivých fází restitučních procesů. Kniha je ilustrována mnoha grafy a tabulkami ze zdrojů Pozemkového fondu, díky těmto přehledně podaným datům a autorovým komentářům si může čtenář udělat vlastní představu o situaci v ČR.

Restituční procesy byly velmi důležitým okamžikem ve změnách vlastnických práv občanů ČR, přesto byly a jsou nejčastěji spojovány pouze s restitucemi církevními, také proto, že byly řešeny až jako poslední a nebyly dosud patřičně uzavřeny. Ostatní části,

Tomáš Hřebík (hrebikt@vse.cz), Vysoká škola ekonomická v Praze, Národohospodářská fakulta. 
tedy likvidace státních podniků, konkurzní procesy nebo převody do vlastnictví obcí, už nejsou veřejnosti tolik známé. Tato publikace by měla pomoci řešit absenci makroekonomických a analytických publikací na toto téma. Publikace o privatizačním procesu poměrně často hledají viníky nebo selhání orgánů odpovědných za privatizaci, avšak u restitučních procesů je tyto zodpovědné osoby mnohem těží dohledat, protože i dostupná data a literatura jsou velmi roztřríštěné. S tím by opět mohlo toto analytické dílo pomoci.

Cílem autora jsou tedy aplikování ekonomických teorií na uváděné restituční procesy, analýza právního rámce a institucionálního zajištění jednotlivých sekcí a následné analýzy a závěry ze zkoumaných procesů. Samotné restituční procesy jsou nadto děleny na malou restituci, dále na restituce mimosoudními rehabilitacemi, zemědělského a lesního majetku, církevního majetku, židovského majetku a historického majetku obcí. Tyto procesy pravděpodobně nebudou dokončeny ani v následujících pěti letech, protože vedených sporů jsou tisíce. Jejich cílem je co nejvíce napravit majetkové křivdy z předchozího období let 1948-1989, což se může jevit jako nereálný úkol, protože během čtyřiceti let přirozeně došlo k změnám, které není možné zpětně zcela vyrovnat. Úkol je to o to náročnější, že deformace vlastnických poměrů zde byla větší než v ostatních zemích východního bloku a také dlouhá nestabilita vedla k několikanásobným změnám vlastníků, zejména u lesního a zemědělského majetku, čímž je průběžně snižována důvěra ve vlastnictví a relativizováno budování dlouhodobého pozitivního vztahu, což ve svém důsledku vede $\mathrm{k}$ tomu, že chybí motivace $\mathrm{k}$ hospodářskému růstu.

Kapitola první pojednává o vlastnických právech a jejich historii od dob ř́mského práva až po současnost. Dále se zde autor zabývá teoriemi zájmových skupin, dobývání renty, vládních selhání, firmy a dalšími. U každé z těchto teorií jsou uvedeni významní autoři a myšlenky pro danou oblast charakteristické.

Druhá kapitola rozebírá jednotlivé restituční procesy nejprve z hlediska právního rámce. Zákon o malé restituci byl pojmenován jako zákon o ,zmírnění následků některých majetkových křivd“, z čehož je patrná snaha o nápravu věcí v rámci současných možností. Teoreticky byl majitel, jehož majetek byl během znárodnění zhodnocen, povinen i tento rozdíl uvést do původního stavu vrácením části svého majetku, prakticky však docházelo téměř vždy $\mathrm{k}$ doplácení rozdílů ze strany státu.

Výjimku z objektů k navrácení tvořily diplomatická a zdravotnická zařízení nebo kulturní památky. Zákon o mimosoudních rehabilitacích je sporný pro svoji diskriminační podmínku, že odškodné může být vypláceno pouze osobám se státním občanstvím tehdejší České a Slovenské Federativní Republiky (ČSFR), čímž porušuje rovnost osob, která je stejně jako základní lidská práva deklarována Chartou OSN a Všeobecnou deklarací lidských práv. Zákon upravující zemědělský a lesní majetek se od předešlého lišil v tom, že nepřripouštěl, aby stát realizovat nárok, pokud dotyčný o pozemek nepožádal, majetek tedy mohl nadále zůstávat v držení aktuální osoby, pokud nebyla státní organizací.

Pokud jde o církevní organizace, ty byly během předchozího období zcela odkázány na financování od státu, který zároveň rozhodoval o počtu duchovních, kteří směli v církvi působit. Přestože po roce 1989 byla tato kontrola uvolněna, díky nenavrácenému majetku zůstala církev nadále závislá na státu, avšak její náklady nadále rostly. Ceny pozemků a jejich rozlohy byly pro usnadnění administrativní práce určovány Pozemkovým fondem, ceny byly stanoveny podle průměrných cen nemovitého majetku v ČR a jejich vývoje.

Restituce židovského majetku spočívala v navracení majetku do rukou oprávněných osob, př́padně jejich př́ibuzných, a to za předpokladu, že se nejednalo o pozemek či 
vlastnictví nezbytné pro chod republiky, případně o součást přírodních rezervací nebo chráněných oblastí. Historický majetek obcí byl vracen obcím v podobě pozemků odpovídajících katastrálním územím, nehledě na to, zda se jednalo o pozemky stavební, lesní či zemědělskou půdu. Dále se předávaly pozemky tvořící funkční celek se stavbou.

Každý z procesů byl zajištěn jiným institucionálním postupem, proto bylo v tomto př́ipadě od autora prozíravé, že tuto sekci doplnil schématy, která vše jednoznačně vysvětlují. V případě malé restituce například kromě osoby oprávněné a osoby povinné mělo důležitou roli Ministerstvo financí (MF) a Ministerstvo pro správu národního majetku a jeho privatizaci (MSNMP), restituční nárok byl postupně dokumentován a kompletován a ve finálním kroku řešen finančním odškodněním. U mimosoudních rehabilitací byl ještě zapotřebí Fond národního majetku (FNM), který vyřizoval uzavření dohody $\mathrm{s}$ oprávněnou osobou, v př́padě že nárok byl oprávněný a majetek bylo možno rovnou vydat. Proces restitucí zemědělského a lesního majetku byl mnohem komplikovanější, do postupu byl zapojen pozemkový úřad rozhodující o oprávněnosti restitučního nároku, který bud' dále předával Pozemkovému fondu, nebo byl postoupen odvolacím orgánům, které byly několikrát změněny, od Ministerstva zemědělství až po krajský soud. Mezi nově vzniklé instituce patřily kromě Ústředního pozemkového úruadu a pozdějšího Státního pozemkového úřadu i Lesy České republiky, tvořené regionálním správami a pracovišti. Židovský majetek a historický majetek obcí byly poměrně jednoduše převáděny z osoby povinné na osoby oprávněné, prričemž u majetku obcí ani neexistovala osoba oprávněná a nebylo potřeba žádných dalších institucí.

Pokud jde o analýzu malé restituce, zajímavým autorovým poznatkem je to, že naturální restituce nebyly žádným zákonem př́mo evidovány, neexistuje tedy žádná databáze ani statistická evidence shrnující celkový objem finančních vyrovnání. Díky tomu zřejmě došlo k pochybnostem převážně u nově vybudovaného majetku. U mimosoudních rehabilitací je podstatným faktem, že osobám byly benevolentně prodávány k majetku i jeho části, které byly až nově vybudovány a které zhodnocovaly původní odňatou majetkovou podstatu. Někteři kupující tedy ke svému minoritnímu podílu přikoupili i značnou část dalšího výhodného majetku.

Na finančních náhradách bylo vyplaceno přes 9 miliard korun, což už si vyžádalo jistý vyšší stupeň administrativy. Realizace restitučního procesu se zemědělským a lesním majetkem naopak od předešlých probíhala za př́sné evidence a dokumentace, což se ukazuje jako velmi užitečné, vzhledem k tomu, že bylo vzneseno okolo půl milionu nároků. Kvůli tomu byly pozemkové úřady pracující s dokumenty v listinné podobě zpočátku zahlceny až do roku 2002, kdy došlo ke zpracování centrální databáze. Efektivita pozemkových úřadů byla značná, celkem $97 \%$ vydaných rozhodnutí bylo plnomocných a vydávalo $76 \%$ z celkově řšené výměry pozemků.

Pozemkové nároky byly vypořádány bud'to náhradami, naturálním plněním, případně finančními náhradami, z čehož finanční náhrady a náhrady v budovách a stavbách tvořily dohromady $86 \%$ finančního objemu. Analýza církevních restitucí je autorem podrobně rozepsána hlavně kvůli své komplikované minulosti, dočteme se zde tedy o historii církevního majetku s důrazem na 20. století. Zásadním problémem, který u církví nastal, bylo dokazování dřívějšího vlastnictví, protože většina oprávněných osob neměla příslušnou dokumentaci, a vznikl spor táhnoucí se do roku 2001, v němž církve požadovaly zvýhodnění, díky kterému by vlastnictví majetku dokazovat nemusely. Roku 2005 církve předložily zcela nový návrh, odmítající od státu plnění naturální, ale naopak požadující 
plnění finančního charakteru v objemu 50 miliard korun, postupně ještě navýšených o inflaci po dobu vyplácení. Nový zákon z roku 2007 tento nárok ještě navýšil na téměř 135 miliard korun kombinovaného naturálního a finančního plnění. Tento návrh byl i díky znaleckému posudku auditorské společnosti zamítnut jako nevýhodný.

Poslední předložený návrh zákona z roku 2012 požaduje plnění v hodnotě 134,75 miliard korun, nicméně autorem je předloženo několik problematických faktů, např́klad netransparentní vymezení majetku, právní problematika, která tvrdí, že se nejedná o skutečné navrácení pořádku do období před rokem 1948, nejistota odloučení církve od státu, nevypověditelnost smlouvy či osvobození církví od daní při budoucím prodeji tohoto majetku.

V seznamu jednotlivých církví se naprostá většina finančního vyrovnání týká církve římskokatolické (47 z 59 miliard korun), následuje církev pravoslavná v českých zemích a církev apoštolská (každá po 1 miliardě korun). V závěru kapitoly autor porovnává jednotlivé restituční procesy a nachází řadu nesourodých prvků v jejich organizaci, např́klad pravomoci statutárních orgánů u malé restituce oproti pravomocím orgánů ve správním řízení u zemědělského a lesního majetku a s rozdílem u historického majetku obcí, který byl převáděn bez zásahu státu, mnohdy chaoticky a nezákonným zpơsobem. Jako další nesrovnalost uváděnou autor uvádí morálně ekonomickou asymetrii u odškodnění za nemožnost nakládat se svým majetkem, která se týkala pouze církevních restitucí, a také cenu vyplácenou za nevydaný metr čtvereční pozemku, která se u necírkevních vlastníků rovnala čtyřem korunám a u církví korunám čtyřiceti, přestože se u obou mělo jednat o cenu průměrnou v celé ČR a tedy cenu totožnou. Dalšími závěry analýzy restitučních procesů jsou souhrny všech pozitiv a negativ pro jednotlivé sekce restitucí, přičemž stojí za zmínku, že výčet negativních důsledků převažuje nad pozitivními.

Třetí kapitola rozebírá téma likvidace státních podniků, a to opět na základě právního rámce několika zákonů a institucionální zajištění. Likvidace státních podniků probíhala bud' zánikem s likvidací, nebo bez likvidace, dvě třetiny státních podniků byly zlikvidovány do roku 2000, poté následoval plynulý pokles. Autor v závěru hodnotí proces likvidace jako nezbytný, avšak nedostatečně harmonizovaný s restitučními a privatizačními procesy, dále také transakčně nákladný, což se dalo odstranit slučováním podniků do několika právnických osob.

Čtvrtá kapitola o insolvenčních řízeních podniků se zabývá odstátňováním majetku, nad kterým stát neměl přímou kontrolu, protože o něm rozhodovali konkurzní správci. Kvůli tomu je opět nemožné jednoduše dohledat seznamy všech majetků, které byly takto odstátněny. Navíc některé procesy nebyly dodnes ukončeny. Všechny tyto procesy jsou bohužel bez pozitivních efektů, nebot' se jedná o ztrátové podniky, které ani prodejem majetku neuhradí hodnotu aktiv.

Poslední, pátá kapitola, zaměřená na transformaci státního majetku do vlastnictví obcí, popisuje převod lesnického i zemědělského majetku do vlastnictví obcí. Zde došlo k řadě státních selhání, protože obecní úřady nebyly připravené na správu majetku takovéhoto rozsahu. Vzniklé bytové fondy tak byly spravovány soukromými firmami, což vedlo ke korupčnímu jednání a nepřiměřeným nákladům. Autor tedy celkově hodnotí hospodaření obcí s nově nabytým majetkem jako neefektivní.

Závěrečnou kapitolu autor pojal jako shrnutí všech aspektů, ke kterým během restitucí došlo, včetně aspektů morálních, restrukturalizace společnosti, nápravy finančních škod, nebo zavedení soukromého vlastnictví místo státního. Celé dílo je tak korunováno 
přesným a uceleným shrnutím restitučního procesu se všemi jeho výhodami a nevýhodami, důsledky a očekávanými dopady v budoucích letech.

Monografie je originálním a významným přínosem pro zkoumání národohospodářských a ekonomických změn v České republice po roce 1989. Je zcela nepochybné, že toto dílo je výsledkem dlouhodobého, širokého a hlubokého výzkumu autora, které navazuje na další jeho publikace, které vytvářejí ucelenou kolekci, umožňující odborné i laické veřejnosti poznání nad převážnou částí transformace národního hospodářství ČR. Za nejhodnotnější výstupy považuji syntetické závěry, které obnažují odlišnost jednotlivých restitučních procesů, nekalé praktiky zájmových skupin, problematičnost a nespravedlivost církevních restitucí včetně jejich negativních dopadů na státní rozpočty v časovém intervalu 30 let.

Nelze pominout ani závěry výzkumu likvidace a konkurzů státních podniků a transformaci státního majetku do měst a obcí, což jsou oblasti, kde došlo k systémovým změnám, kterými se dosud žádný autor ani okrajově nezabýval. Význam těchto procesů není zanedbatelný z hlediska objemu majetku, který tyto procesy řešily. Za zcela alarmující závěry je nutno považovat neexistenci jakékoliv evidence o majetkových a finančních tocích, o transakčních nákladech a zejména o závěrečné bilanci těchto doplňkových procesů. Po prostudování této knihy je možno nalézt odpovědi na hypotézy či otázky, $\mathrm{z}$ nichž některé jsem zmínil $\mathrm{v}$ úvodu této recenze. $\mathrm{Z}$ dlouhodobého výzkumu autora vyplývá, že restituční procesy nebyly pouze nápravou majetkových křivd, ale byly též zneužity ve prospěch zájmových skupin, kterým se podařilo dobýt a nadále dobývat rentu v miliardových hodnotách na úkor daňových poplatníků a běžných restituentů vůbec.

Publikace rovněž dává odpověd' na otázku, proč dosud nikdo nezkoumal tyto procesy, at' už dílčím či komplexním zpơsobem. Jedná se o problematiku, která je mimořádně náročná z hlediska ekonomického, právního i z hlediska obstarávání dat a podkladů právě $\mathrm{s}$ ohledem na to, že neexistuje žádná literatura a že tyto procesy nebyly řízeny homogenním zpo̊sobem ze strany státu, resp. některé nebyly řízeny vůbec, a zejména s ohledem na odbornou znalost a erudici těchto specifických procesů, které ve své podstatě dosud neřeší žádná teoretická díla.

Závěrem bych rád uvedl nejpodstatnější klady recenzované publikace. Především bych chtěl vyzdvihnout autorův velmi ambiciózní cíl z hlediska šíře i hloubky zkoumání, který charakterizoval jako: „... zpracování základních teoretických východisek a testování praktické aplikovatelnosti dotčených ekonomických teorií renomovaných ekonomických fundamentalistů, strukturované analýzy právního rámce, institucionálního zajištění, vlastního vývoje a makroekonomické a statistické analýzy restitučního procesu jako celku.“"Autor v této monografii předkládá na základě důsledné aplikace systémového př́stupu k analýze a syntéze rozbor jednoho z nejdůležitějších témat současné etapy hospodářské politiky. Kvalita odborné ekonomické terminologie, stylistické úrovně a jazykového aparátu je na solidní úrovni, navzdory náročnému národohospodářskému tématu, velmi složité struktuře práce a složitému syntetickému pojetí. Navíc je Zemanova práce pro čtenáře jak z odborné, tak laické veřejnosti srozumitelná, zajímavá a čtivá.

Oceňuji otevřený, odvážný, nekompromisní a přísně systémový postoj autora. Autor se velmi důsledně věnoval zpracování statistických dat, resp. jejich pořízení, roztřídění a následnému rozboru. Dokázal oddělit významná fakta od nevýznamných, zpracovat celý zkoumaný časový interval 20 let do srozumitelné podoby a v přehledné struktuře s mimořádnou vypovídací schopností. Prakticky všechna data a texty jsou původní, dosud 
nepublikované, což ve vazbě na další výše hodnocené parametry vyjadřuje vysokou odbornou vědeckou hodnotu díla. Jedná se o významný příspěvek $\mathrm{k}$ moderním národohospodářským dějinám ČR, jehož hodnota bude oceněna pravděpodobně až s určitým časovým odstupem.

\section{Anotace}

\section{Jaroslav Nenadál: SYSTÉMY MANAGEMENTU KVALITY. CO, PROČ A JAK MĚŘIT}

Praha: Management Press, 2016. 1. vydání. 304 stran. ISBN 978-80-7261-426-4.

Jestliže mají manažeři na všech úrovních řízení organizací přijímat a prosazovat objektivní rozhodnutí, musejí tak činit na základě faktů, nezkresleně popisujících realitu. Fakta jsou ve své podstatě analyzovaná data a data nelze získávat jinak než měřením a monitorováním. Moderní systémy managementu kvality počítají s celou řadou takových měření a monitorování, na které ale $\mathrm{v}$ mnoha př́padech naše organizace nejsou metodicky a znalostně připraveny. Cílem publikace je proto poskytnout všem zájemcům návody na to, jak tzv. systémová měření v praxi realizovat a jak se získanými údaji nakládat, aby byl umožněn trvalý rozvoj systémů managementu.

V úvodní kapitole najde čtenář informace o principech pokročilých systémů managementu kvality a požadavcích, resp. doporučeních směrem k systémovým měřením v nejnovějších verzích normy ISO 9001:2015 a EFQM Modelu excelence. Následující tři kapitoly jsou vyhrazeny informacím o podstatě a postupech tří různých skupin měření v systémech managementu kvality: (i) měřením v rámci zpětné vazby, kde jsou soustředěny informace o měření spokojenosti a zejména loajality zákazníků i dalších zainteresovaných stran, (ii) měřením výkonnosti jednotlivých procesů, systémů managementu kvality, dodavatelů, benchmarkingu a možnostech vyjadřování výkonnosti pomocí finančních měřítek, (iii) měřením vyzrálosti systémů managementu se speciálním důrazem na procesy sebehodnocení, resp. posuzování rizik v procesech systémů managementu kvality.

Poslední kapitola pak vysvětluje smysl všech systémových měření, zejména ve vazbě na procesy přezkoumávání systémů managementu vrcholovým vedením a aktivity neustálého zlepšování a inovací. Popisy jednotlivých metodik měření jsou doplněny praktickými př́iklady.

Publikace se snaží nejen objasnit teoretická východiska jednotlivých systémových měření, ale především formou návodů inspirovat další rozvoj měření a monitorování, bez kterých se organizace, pohybující se $\mathrm{v}$ náročném konkurenčním prostředí prostě nemohou obejít. Vysoce aktuální se stává i proto, že reaguje na všechny změny v požadavcích a doporučeních v normách ISO 9001:2015, resp. ISO 9004:2009, ale zároveň reaguje i na některé podněty směrem k systémovým měřením, které normy ISO ř. 9000 vůbec neobsahují, ale různými modely excelence jsou považována za zásadní.

Kniha je určena pro manažery všech typů organizací, jakož i pro studenty a pedagogy vysokých škol technického a ekonomického zaměření. Ti by zde měli najít odpověd’ nejenom na otázky, co to systémová měření v managementu kvality jsou, ale měla by jim zejména poskytnut návod na to, jak taková měření plánovat, realizovat a prímo provázat s rozvojem systémů managementu organizací a trvalým zlepšováním jejich výkonnosti a konkurenční schopnosti. 